\title{
PRELIMINARY DIAGNOSES OF NEW SPECIES OF NON-MARINE
} MOLLUSCA FROM THE HAWAIIAN ISLANDS. PART II.

\author{
By E. R. Sykes, B.A., F.Z.S., ete.
}

Read 11th June, 1897.

Since the first of these papers appeared (Oct. 1896, v. ante, p. 126), Mr. Perkins has finished his exploration and returned from the Hawaiian Islands, so that the work of preparing the final report can now be proceeded with; nevertheless, I have thought it advisable to issue these few diagnoses, drawn out prior to his return, and thereby to conclude the very brief series of descriptions here issued without illustrations.

\section{Vitrea (?) Molokaiensis, n.sp.}

Testa depressa, albido-hyalina, tenuis, late et aperte umbilicata (umbilicus circa $1 \mathrm{~mm}$. latus), omnino sub lente eleganter regulariterque costulato-striata, nitida; spira perdepressa-conoidea, obtusula,

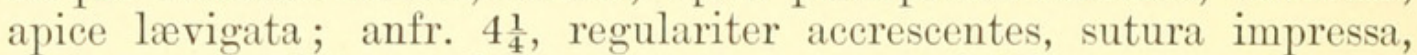
ultimus rotundatus, subdepressus ; apertura subobliqua, ovato-lunata, relative ampla ; peristoma simplex, tenue. Diam. max. $4 \cdot 6$, min. $4 \mathrm{~mm}$; alt. $2 \mathrm{~mm}$.

Hab.-Forest above Pelekunu, Molokai (Perkins).

For remarks, see under the next species.

\section{Vitrea (?) Lanaiensis, n.sp.}

Testa V. Molokaiensi similis sed minor, umbilico profundiore et minore (circa $\cdot 5 \mathrm{~mm}$. lato), striis magis approximatis et levioribus, infra fere obsoletis. Diam. $\max .3 \cdot 2$, min. $3 \mathrm{~mm}$; alt. $1 \cdot 2 \mathrm{~mm}$.

Hab.-Mountains of Lanai, behind Koele (Perkins).

M. Ancey has placed ${ }^{1}$ Hetix Sandwicensis, Pfr., H. pauxillus, Gould (=pusillus, Gould non Lowe), and a new species, H. Baldwini, in Hyalinia. The first species will, I think, eventually prove not to really come from the Hawaiian Islands, but to be the young of some South American Systrophia. M. Ancey has kindly lent me the type of his new species, and from a comparison of it with the figures and description of Gould's Helix pauxillus, ${ }^{2}$ I think they are only two forms of the same species. Both come from the same island (Maui); both have four whorls; one measures diam. $4 \cdot 5$, alt. $2 \mathrm{~mm}$., the other diam. 5 , alt. $2 \cdot 125 \mathrm{~mm}$. ; both are striate above and smoother below; one is "pertenuis," the other "tenuis" ; both are "depressa"; one is " aperte umbilicata," " umbilicus mediocris," the other " umbilicus

1 Bull. Soc. Malac. France, vol. vi, p. 192.

2 U.S. Explor. Exped., Moll. p. 40, pl. iii, fig. 46. 
angustus, pervius": in short, I can trace no material differences between them. There appears, therefore, to be a compact little group of three species-one from Maui, one from Molokai, and one from Lanai. Vitrea Mololaiensis may be at once separated from $V$. pauxillus by its wider and more open umbilicus, and by the fact that the sculpture is strongly continued over the base; while $V$. Lanaiensis is intermediate in the umbilical perforation, and is a more compressed shell than $V$. pauxillus.

\section{Kaliella Konaensis, n.sp.}

Testa conico-pyramidalis, brunnea, subtenuis, subimperforata, supra sub lente dense et obsoletissime lineis incrementibus sculpta, infra lævior, nitida; spira bene elevata, apice obtusa, lævi; anfr. $5 \frac{3}{4}$, convexiusculi, lente regulariterque accrescentes, sutura valde impressa, ultimus ad peripheriam carinatus, basi inflatus; apertura securiformis; peristoma simplex, tenue, acutum, margine columellari leviter reflexo. Diam. max. $3 \cdot 5$, min. $3 \cdot 2 \mathrm{~mm}$; alt. $2 \mathrm{~mm}$.

Hab.-Nt. Kona, Hawaii, at 3,000 feet (Perkins).

A remarkable little shell which seems to fall into Kaliella; it may, however, possibly be placed, when we are acquainted with the anatomy, near the Japanese forms of Trochoconulus.

\section{Succinea Konaensis, n.sp.}

Testa elongato-ovata, rugoso-striata, pellucida, pallide succinea, rare rufescenti-succinea, spira elongato-conica, apice papillata, sutura valde impressa ; anfr. $3 \frac{1}{2}$, rapide accrescentes, ultimo magno ; apertura ovata, fere verticalis, columella subarcuata, peristomate acuto, basi expansiusculo. Alt. $9 \cdot 5$, lat. $5 \mathrm{~mm}$.

Hab.-Mt. Kona, Hawaii, at 4,000 feet (Perkins).

The large number of unfigured species described from the Hawaiian Islands, renders the identification of specimens a somewhat difficult task, but the present form does not appear to quite agree with any named species. 


\section{$2 \mathrm{BHL}$ Biodiversity Heritage Library}

Sykes, E. R. 1897. "PRELIMINARY DIAGNOSES OF NEW SPECIES OF NON-MARINE MOLLUSCA FROM THE HAWAIIAN ISLANDS. PART II." Proceedings of the Malacological Society of London 2, 298-299.

View This Item Online: https://www.biodiversitylibrary.org/item/52043

Permalink: https://www.biodiversitylibrary.org/partpdf/202659

\section{Holding Institution}

Smithsonian Libraries

\section{Sponsored by}

Smithsonian

\section{Copyright \& Reuse}

Copyright Status: Public domain. The BHL considers that this work is no longer under copyright protection.

This document was created from content at the Biodiversity Heritage Library, the world's largest open access digital library for biodiversity literature and archives. Visit BHL at https://www.biodiversitylibrary.org. 